\title{
Insulin receptor : tyrosine kinase activity and insulin action
}

\author{
R. Ballotti, Y. Le Marchand-Brustel, S. Gammeltoft and \\ E. Van Obberghen
}

INSERM U 145, Faculté de Médecine, 06034 Nice, France

(14th meeting of the INRA Development Group, Clermont-Ferrand, 25-27 May 1988)

Summary - The first step in insulin action consists in binding of the hormone to specific cell surface receptors. This receptor displays two functional domains : an extracellular $\alpha$-subunit containing the majority or the totality of the hormone binding site and an intracellular $\beta$-subunit possessing insulin-stimulated tyrosine kinase activity.

A general consensus has been reached in favour of the idea that this receptor enzymic function is essential for generation of the metabolic and growth-promoting effects of insulin. Concerning the mechanism of transmembrane signalling, we like to think that interaction of insulin with the receptor $\alpha$-subunit triggers a conformational change, which is propagated to the $\beta$-subunit and activates it. The active receptor kinase leads then to the phosphorylation of cellular protein substrates, which are likely to belong to two broad categories, those generating metabolic effects of insulin and those resulting in growth-promoting effects. The phosphorylated and active substrates then generate the final effects of insulin

Insulin receptors - hormone signalling - tyrosine kinase

Résumé- Récepteur de l'insuline : activité tyrosine kinase et rôle dans le mécanisme d'action de l'hormone. La première étape du mécanisme d'action de l'insuline implique la liaison de I'hormone à des récepteurs spécifiques exprimés au niveau de la membrane plasmique. Le récepteur présente deux domaines fonctionnels : un domaine extracellulaire liant l'insuline, contenu dans la sous-unité $\alpha$; une activité tyrosine-kinase stimulée par l'insuline et contenue dans la partie intracellulaire de la sous-unité $\beta$. Un large consensus s'est dégagé sur le fait que cette activité enzymatique du récepteur est requise pour la génération des effets métaboliques et mitogéniques induits par l'insuline. En ce qui concerne le mécanisme de transmission du message hormonal, nous pensons que la liaison de l'hormone à la sous-unité $\alpha$ provoque une modification de conformation qui est répercutée au niveau de la sous-unité $\beta$ et en active la fonction kinase. La kinase ainsi activée phosphoryle deux types de substrats cellulaires : ceux qui génèreront les effets métaboliques de l'insuline et ceux qui induiront ses effets sur la croissance cellulaire. Activées par la phosphorylation, ces protéines pourraient induire les différentes réponses biologiques de l'insuline.

récepteur de l'insuline - activation cellulaire - tyrosine kinase 


\section{INTRODUCTION}

Regulation of cellular metabolism and growth by insulin is the result of a series of events initiated by the interaction of the hormone with its cell surface receptors. The insulin receptor structure was elucidated through a variety of techniques (Van Obberghen, 1984) and, more recently, the aminoacid sequence of the human insulin receptor precursor has been unravelled by recombinant DNA technology (Ullich et al., 1985; Ebina et al., 1985). Despite this progress, the molecular mechanism of insulin action is still not entirely understood with regard to the events following receptor binding and leading to the ultimate cellular responses. However, over the years, considerable evidence has been gathered indicating that reversible phosphorylation contributes to the mechanism of insulin action (Denton, 1986). In addition, a promising discovery was made by the demonstration that the insulin receptor is an insulinsensitive protein kinase (Kasuga et al., 1982a; Van Obberghen \& Kowalski, 1982; Petruzzelli et al., 1982). This observation is of particular interest for our understanding of insulin-regulated processes, since it is now recognized that phosphorylationdephosphory-lation of proteins is a mechanism whereby many cellular functions are regulated by hormones and neurotransmitters. Furthermore, protein kinases are also constituents of receptors for several growth factors, implying that receptor kinase activity may represent a general mechanism in transmembrane signalling of hormones and growth factors.

\section{INSULIN RECEPTOR PHOSPHORYLA- TION}

In intact cells, insulin stimulates the phosphorylation of its receptor $\beta$ subunit (Van Obberghen \& Kowalski, 1982; Kasuga et al., 1982a). In these experiments, cells were preincubated with [ $\left.{ }^{32} \mathrm{P}\right] \mathrm{P}_{\mathrm{i}}$ to label cellular ATP, solubilized, and the glycoproteins purified on WGA-agarose. Immunoprecipitation by antibodies to insulin receptors followed by SDS/PAGE under reducing conditions and autoradiography revealed a labeled band $\left(M_{\mathrm{r}} 95 \mathrm{k}\right)$, the phosphorylation of which was stimulated by insulin. Its identity with insulin receptor $\beta$ subunit was established based on its appropriate electrophoretic mobility and on the fact that it was not precipitated with nonimmune serum. In intact cells, phosphoaminoacid analysis of the insulin receptor $\beta$ subunit showed phosphorylation of serine, threonine, and tyrosine under basal conditions. Insulin induced a rapid, several-fold increase in ${ }^{32} \mathrm{P}$ incorporation on tyrosine, followed by a slower rise in labeling of phosphoserine (Kasuga et al., 1982; Gazzano et al., 1983; White et al., 1985b; Ballotti et al., 1987).

Subsequently, insulin-stimulated phosphorylation of the insulin receptor $\beta$ subunit was demonstrated in cell-free systems using $\left[\gamma^{32}\right.$ P]ATP and purified receptors (Van Obberghen \& Kowalski, 1982; Kasuga et al., 1982c; Van Obberghen et al., 1983; Shia \& Pilch, 1983; Petruzzelli et al., 1982; 1984).

These purified receptor preparations exhibited insulin-stimulated protein kinase activity which catalysed phosphorylation of 
both the $\beta$ subunit and exogenous substrates. With a highly purified receptor, the phosphorylation occurred exclusively on tyrosine residues under basal conditions, and insulin stimulatory action was accounted for by a several-fold increase in phosphotyrosine. Thus, the tyrosine kinase appeared as a constituent of the insulin receptor. Further, the $\beta$ subunit contains an ATP-binding site as demonstrated by covalent affinity labeling (Van Obberghen et al., 1983; Shia \& Pilch, 1983; Roth \& Cassell, 1983). The simultaneous presence of phosphorylation sites and an ATP binding site on the receptor $\beta$ subunit indicates that the insulin receptor acts as its own tyrosine kinase. Further proof is the demonstration that the insulin-binding activity and insulindependent tyrosine-kinase activity copurified to homogeneity at a constant stoichiometric ratio (Petruzzelli et al., 1984). In addition, insulin binds to and promotes phosphorylation of the insulin receptor precursor $\left(M_{r} 210 \mathrm{Kd}\right)$ (Rees-Jones et al., 1983).

\section{BIOCHEMISTRY OF THE INSULIN RE- CEPTOR KINASE}

Following the identification of the insulin receptor protein kinase activity, its biochemical properties have been investigated in detail. For original references, see Gammeltoft \& Van Obberghen (1986).

\section{ROLE OF INSULIN RECEPTOR TYRO- SINE KINASE IN HORMONE ACTION}

\section{Characteristics of insulin receptor tyro- sine kinase}

Since the discovery that the insulin receptor is an insulin-dependent protein tyrosine kinase, it was anticipated that this receptor enzymic function was involved in insulin action (Gazzano et al., 1983). For the validity of this contention, the following five criteria were expected to be fulfilled. First, the insulin dose-response relationship of the kinase should be within the physiological range and correlate with that of receptor binding. Several authors found that the kinase activation was half-maximal at an insulin concentration of 2-5 $\mathrm{nM}\left(\mathrm{ED}_{50}\right)$, which corresponded to the apparent $K_{d}$ of the receptor-insulin complex of the same solubilized receptor preparations (Kasuga et al., 1982b; Shia \& Pilch, 1983; Petruzzelli et al., 1984; Sadoul et al., 1985). In contrast, a dissociation between doseresponse curves of insulin binding and kinase activation was observed with soluble receptors from rat liver and human erythrocytes (Grigorescu et al., 1983). In this instance, the apparent $K_{d}$ exceeded the $E D_{50}$ by a factor of $3-10$, suggesting that the phenomenon of "spare receptors", observed for other insulin actions, was also applicable for kinase activation. It is not clear whether these findings are explained 
by differences in tissues, purification procedures, or assay methods. In conclusion, in most instances, the receptor kinase is activated by insulin concentrations within a physiological range corresponding to receptor binding.

Second, the receptor kinase should be capable of phosphorylating cellular substrates other than the receptor itself, in order to propagate the insulin response. The insulin receptor kinase can phosphorylate a number of substrates on tyrosine in vitro, although none of the proteins tested are proven to be physiologically relevant substrates. The first two "putative" substrates described were a 110-120 kDa protein and a $185 \mathrm{kDa}$ protein. In 1985, two laboratories independently identified in purified glycoproteins from rat liver and rabbit brown adipose tissue, a cellular protein "substrate" of $M_{r} 110 \mathrm{~K}$ for the insulin receptor kinase (Sadoul et al., 1985; ReesJones \& Taylor, 1985). This glycoprotein appears as a monomeric structure and is not part of the insulin receptor itself. Phosphorylation of the $M_{r} 110 \mathrm{~K}$ protein and of the receptor $\beta$ subunit were stimulated by insulin in a remarkably similar dosedependent fashion $\left(E D_{50} \approx 1 \mathrm{nM}\right)$. In addition, kinetic studies suggested that phosphorylation of the $M_{r} 110 \mathrm{~K}$ protein occurred after activation and phosphorylation of the insulin receptor kinase. The nature and function of this endogenous substrate is as yet unknown. In the same period, a different putative substrate for the insulin receptor kinase was identified in a hepatoma cell line, Fao (White et al., 1985a). This $M_{r} 185 \mathrm{kDa}$ substrate does not contain carbohydrate moieties and appears to be monomeric. Since the reports on these two "putative" substrates, a number of other phosphoproteins have been described, including an $M_{r} 15 \mathrm{kDa}$ that may play a role in insulin-mediated glucose transport (Bernier et al., 1987). However, at present, it remains to be seen whether any of these proteins have a physiological significance. One is forced to admit that, despite intensive efforts, extremely little is known about "putative" substrates. This is likely due to the fact that they are rare and labile. In addition, as expected from the large array of biological responses induced by insulin, a whole series of nonabundant regulatory proteins are likely to exist to account for the metabolic and growth-promoting effects of insulin.

The third criterion is reversibility of insulin receptor phosphorylation. To exert a regulatory function, the phosphorylated and activated receptor kinase should return to basal activity through a dephosphorylation reaction. Lectin-purified receptor preparations were found to contain phosphatase activity which slowly reduced the ${ }^{32} \mathrm{P}$ content of phosphorylated receptor and was insulin-independent (Kowalski et al., 1983). Exposure of phosphorylated insulin receptor to alkaline phosphatase resulted in the removal of about $50 \%$ of the $\beta$ subunit phosphotyrosine and about $65 \%$ reduction in kinase activity ( $Y u$ \& Czech, 1984). Thus, the insulin receptor kinase can be de-activated through dephosphorylation of tyrosine residues.

The fourth criterion concerns the specificity of insulin effect on its receptor kinase. Several insulin analogues stimulated receptor phosphorylation with potencies relative to porcine insulin and identical with their relative binding affinities and with potencies in other assay systems (Kasuga et al., 1982a; Grigorescu et al., 1983). Finally, polyclonal antisera to insulin receptor, which exert insulin-like effects in several cell types, were also able to stimulated the receptor tyrosine kinase (Gammeltoft \& Van Obberghen, 1986; Gherzi et al., 1987). In conclusion, the insulin effect on receptor phosphorylation has the affinity 
and specificity of a typical insulin receptor mediated event.

Combined, the kinase activity of the insulin receptor seems to be a fundamental receptor property, since whenever insulin receptors are present, insulin-stimulated autophosphorylation occurs (Gammeltoft et al., 1984, 1985; Gazzano et al., 1985; Grigorescu et al., 1983; Kasuga et al., 1982a, c; Petruzzelli et al., 1984; Shia \& Pilch, 1983; Tanti et al., 1986; Van Obberghen \& Kowalski, 1982). An important feature of the insulin receptor tyrosine kinase is that receptor autophosphorylation on one or more tyrosyl residues activates the receptor kinase towards exogenous substrates without affecting the insulin-binding caracteristics (Rosen et al., 1983; Yu \& Czech, 1984).

\section{Insulin receptor tyrosine kinase and hormone action}

A general consensus has been reached for a role of insulin receptor kinase in hormone action. The first series of suggestive observations was provided by studies, showing that alterations in insulin action are associated with parallel alterations in insulin receptor tyrosine kinase activity. Thus, the receptor kinase is impaired in various insulin-resistant states including the syndrome of extreme insulin resistance type A (Grunberger et al., 1984), melanoma cell cultures (Häring et al., 1984), goldthioglucose obese mice (Le MarchandBrustel et al., 1985), and streptozotocin diabetic rats (Kadowaki et al., 1984). Conversely, insulin receptor kinase is hyperactive in insulin hyperresponsive adipocytes of young obese Zucker rats (Debant et al., 1987). Further, insulinomimetic agents (vanadate, lectins, trypsin) increased receptor autophosphorylation (Tamura et al.,
1983; Roth et al., 1983). Introduction into mammalian cells of a monoclonal antibody which inhibits insulin receptor kinase, blocks the rapid effects of insulin (Morgan \& Roth, 1987). Conversely, microinjection of antiphosphotyrosine antibodies, which stimulate the insulin receptor kinase, induces enhanced insulin-evoked glucose transport and aminoacid uptake (Ballotti et al., 1989).

The most convincing and elegant evidence for the idea that insulin action depends on receptor protein tyrosine kinase activity, comes from mutagenesis experiments involving the receptor. Thus, insulin receptors mutated on the ATP binding site, lack protein tyrosine kinase activity and fail to mediate insulin post-receptor effects, including glucose transport, glycogen synthesis, S6 kinase activity and thymidine uptake (Chou et al., 1987).

\section{SERYL (AND THREONYL) PHOSPHOR- YLATION OF INSULIN RECEPTORS}

In intact cells, the rapid insulin-stimulated phosphorylation of its receptor on tyrosine is followed by a slower serine phosphorylation (Kasuga et al., 1982c; Gazzano et al., 1983; White et al., 1985b; Ballotti et al., 1987; Pang et al., 1985). In addition, with partially purified insulin receptor, insulinstimulated phosphorylation of both tyrosine and serine on its receptor (Kasuga et al., 1982; Zick et al., 1983), as well as on exogenous substrates (Gazzano et al., 1983; Ballotti et al., 1986) was shown. The serine kinase activity appears to be noncovalently associated with the receptor and is removed during further purification, because highly purified receptor solely displayed tyrosine kinase activity. The relationship between the two protein kinase 
activities associated with the receptor, and their cellular role, remain to be established. At least two possibilities exist, one in which the two kinase activities serve separate cellular functions, and another with sequential kinase activation (Gazzano et al., 1983). According to the first model, the tyrosine kinase would be involved in insulin's growth-promoting action similar to tyrosine phosphorylations, mediating cellular responses to growth factors and to cellular and retroviral oncogene proteins (Hunter \& Cooper, 1985). In contrast, the serine kinase activities would play a role in insulin's metabolic actions. All kinases involved in the control of intermediary metabolism are indeed serine- or threoninespecific. In the second model, the two types of kinases are activated sequentially. Insulin binding to receptor leads to activation of the constituent tyrosine kinase, which induces activation of the receptorassociated serine kinase(s), accounting for the generation of cellular responses to insulin.

In contrast to insulin receptor autophosphorylation on tyrosine residues, phosphorylation of insulin receptor $\beta$ subunit on serine and threonine residues results in a decrease in receptor tyrosine kinase activity. This has been observed in the following situations :

- intact cells treated either with phorbol esters, thought to act through protein kinase C (Jacobs et al., 1983; Häring et al., 1986), or with agents leading to an increase in cellular cAMP (Stadtmauer \& Rosen, 1986);

- purified insulin receptors exposed to cAMP-dependent protein kinase (Roth \& Beaudoin, 1987) or protein kinase C (Bollag et al., 1986).

The role of serine and threonine phosphorylation of the insulin receptor remains a matter of speculation. It is tempting to suggest that at least part of the antagonistic action of some hormones, which oppose insulin's effects and act through cAMP dependent protein kinase or protein kinase $C$, is mediated by seryl and threonyl $\beta$ subunit phosphorylation with a concomitant decrease in receptor tyrosine kinase activity. Furthermore, like to think that seryl and threonyl insulin receptor phosphorylation might also be the endpoint of a negative feed-back loop in the regulation of insulin action. According to this idea, the activated insulin receptor tyrosine kinase would phosphorylate and activate a series of functional substrates, one of which would be a serine/threonine kinase. This kinase would phosphorylate the insulin receptor on serine/threonine residues leading to reduced tyrosine kinase activity and, consequently, to a decreased insulin signal.

\section{SIGNAL TRANSDUCTION}

A large body of evidence establishes insulin receptor tyrosine kinase as fundamental property. of the receptor and indicates that this receptor enzymic function is essential for generation of the metabolic and growth-promoting effects of insulin. The insulin receptor displays two functional domains, an extracellular insulin binding $\alpha$ subunit and an insulin-responsive protein kinase contained within the intracellular domain of the $\beta$ subunit. At present, it has not been established how hormone recognition at the cell surface transmits a signal to the cytoplasmic receptor domain through a unique transmembrane stretch. The simplest mechanism would be that interaction of insulin with the receptor $\alpha$ subunit trigger a conformational change which is propagated at the level of the contact region between $\alpha-\beta$ subunits, resulting in ac- 
tivation of the receptor kinase. How the activated receptor kinase transduces the hormone signal is not known at present. We favour the idea that the insulin-stimulated receptor kinase leads to phosphorylation of cellular protein substrates, which are likely to belong to two broad categories those generating metabolic effects of insulin and those resulting in growth-promoting effects.

\section{REFERENCES}

Ballotti R., Kowalski A., Le Marchand-Brustel Y. \& Van Obberghen E. (1986) Presence of an insulin-stimulated serine kinase in cell extracts from IM-9 cells. Biochem. Biophys. Res. Commun. 139, 179-185

Ballotti R., Kowalski A., White M.F., Le Marchand-Brustel Y. \& Van Obberghen E. (1987) Insulin stimulates tyrosine phosphorylation of its receptor $\beta$ subunit in intact rat hepatocytes. Biochem. J. 241, 99-104

Ballotti R., Scimeca J.C., Kowalski A. \& Van Obberghen E. (1989) Antiphosphotyrosine antibodies modulate insulin receptor kinase activity and insulin action. Cellular Signalling 1, 195-204

Bernier M., Laird D.M. \& Lane M.D. (1987) Insulin-activated tyrosine phosphorylation of a 15kilo-dalton protein in intact 3T3-L1 adipocytes. Proc. Natl. Acad. Sci. (USA) 84, 1844-1848

Bollag G.E., Roth R.A., Beaudoin J., MochlyRosen D., Koshland Jr D.E. (1986) Protein kinase $C$ directly phosphorylates the insulin receptor in vitro and reduces its protein-tyrosine kinase activity. Proc. Natl. Acad. Sci. 83, 58225824

Chou C.K., Dull T.J., Russell D.S., Gherzi R., Lebwohl D., Uilrich A. \& Rosen O.M. (1987) Human insulin receptors mutated at the ATP. binding site lack protein tyrosine kinase activity and fail to mediate postreceptor effects of insulin. J. Biol. Chem. 262, 1842-1847

Debant A., Guerre-Millo M., Le MarchandBrustel Y., Freychet P., Lavau M. \& Van Obberghen $E$. (1987) The adipocyte insulin receptor ki- nase from young obese Zucker rats is hyperresponsive to insulin. Amer. J. Physiol. 252, E273E278

Denton R.M. (1986) Early events in insulin actions. In : Advances in Cyclic Nucleotide and Protein Phosphorylation Research (Greengard P. \& Robison A., eds), Raven Press, New York, pp. 293-341

Ebina Y., Ellis L., Jarnagin K., Edery M., Graf L., Clauser E., Ou J.H., Masiarz F., Kan Y.W., Goldfine I.D., Roth R.A. \& Rutter W.J. (1985) The human insulin receptor cDNA : the structural basis for hormone-activated transmembrane signalling. Cell 40, 747-758

Gammeltoft S., Kowalski A., Fehlmann M. \& Van Obberghen E. (1984) Insulin receptors in rat brain : insulin stimulates phosphorylation of its receptors $\beta$-subunit. FEBS Lett. 172, 87-90

Gammeltoft S., Haselbacher G.K., Humbel R.E., Fehlmann M., Van Obberghen E. (1985) Two types of receptors for insulin-like growth factors in mammalian brain. EMBO J. 4, 3407-3412

Gammeltoft S. \& Van Obberghen E. (1986) Protein kinase activity of the insulin receptor. Biochem. J. 235, 1-11

Gazzano H., Kowalski A., Fehimann M. \& Van Obberghen E. (1983) Two different protein kinase activities are associated with the insulin receptor. Biochem. J. 216, 575-582

Gazzano H., Halban P., Prentki M., Ballotti R., Brandenburg D., Fehlmann M. \& Van Obberghen E. (1985) Identification of functional insulin receptors on membranes from an insulin producing cell line (RINm5F). Biochem. J. 226, 867872

Gherzi R., Russel D.S., Taylor S.I. \& Rosen O.M. (1987) Reevaluation of the evidence that an antibody to the insulin receptor is insulinmimetic without activating the protein tyrosine kinase activity of the receptor. J. Biol. Chem. 262, 16900-16905

Grigorescu F., White M.F. \& Kahn C.R. (1983) Insulin binding and insulin-dependent phosphorylation of the insulin receptor solubilized from human erythrocytes. J. Biol. Chem. 258, 1370813716

Grunberger G., Zick Y. \& Gorden P. (1984) Defect in phosphorylation of insulin receptors in cells from an insulin resistant patient with normal insulin binding. Science 223, 932-934

Häring H.U., White M.F., Kahn C.R., Kasuga M., Lauris V., Fleischmann R., Murray M. \& Pawe- 
lek J. (1984) Abnormality of insulin binding and receptor phosphorylation in an insulin-resistant melanoma cell line. J. Cell Biol. 99, 900-908

Häring H.U., Kirsch D., Obermaier B., Ermel B. \& Machicao F. (1986) Tumor-promoting phorbol esters increase the $\mathrm{Km}$ of the ATP binding site of the insulin receptor kinase from rat adipocytes. J. Biol. Chem. 261, 3869-3875

Hunter T. \& Cooper J.A. (1985) Protein-tyrosine kinases. Ann. Rev. Biochem. 54, 897-930

Jacobs S., Sahyoun N.E., Saltiel A.R. \& Cuatrecasas P. (1983) Phorbol esters stimulate the phosphorylation of receptors for insulin and somatomedin C. Proc. Natl. Acad. Sci. USA 80, 6211-6213

Kadowaki T., Kasuga M., Akanuma Y., Ezaki O. \& Takaku F. (1984) Decreased autophosphorylation of the insulin receptor-kinase in streptozotocin-diabetic rats. J. Biol. Chem. 259, 1420814216

Kasuga M., Karlsson F.A. \& Kahn C.R. (1982a) Insulin stimulates the phosphorylation of the 95000-dalton subunit of its own receptor. Science 215, 185-187

Kasuga M., Zick Y., Blithe D.L., Crettaz M. \& Kahn C.R. (1982b) Insulin stimulates tyrosine phosphorylation of the insulin receptor in a cell free system. Nature 298, 667-669

Kasuga M., Zick Y., Blithe D.L., Karisson F.A., Häring H.U. \& Kahn C.R. (1982c) Insulin stimulation of phosphorylation of the beta subunit of the insulin receptor. Formation of both phosphoserine and phosphotyrosine. J. Biol. Chem. 257, 9891-9894

Kowalski A., Gazzano H., Fehimann M. \& Van Obberghen E. (1983) Dephosphorylation of the hepatic insulin receptor : absence of phosphatase activity in purified receptors. Biochem. Biophys. Res. Commun. 117, 885-893

Le Marchand-Brustel Y., Grémeaux T., Ballotti R. \& Van Obberghen E. (1985) Insulin receptor kinase is defective in skeletal muscle of obese mice. Nature 315, 676-679

Morgan D.O. \& Roth R.A. (1987) Acute insulin action requires insulin receptor kinase activity : introduction of an inhibitory monoclonal antibody into mammalian cells blocks the rapid effects of insulin. Proc. Natl. Acad. Sci. USA 84, 41-45

Pang D.T., Sharma B.R., Schafer J.A., White P.F. \& Kahn C.R. (1985) Predominance of tyro- sine phosphorylation of insulin receptors during the initial response of intact cells to insulin. $J$. Biol. Chem. 260, 7131-7136

Petruzzelli L.M., Ganguly S., Smith C.J., Cobb M.H., Rubin C.S. \& Rosen O.M. (1982) Insulin activates a tyrosine-specitic protein kinase in extracts of 3T3-L1 adipocytes and human placenta. Proc. Natl. Acad. Sci. USA 79, 67926796

Petruzzelli L.M., Herrera R. \& Rosen O.M. (1984) Insulin receptor is an insulin-dependent tyrosine protein kinase : copurification of insulinbinding activity and protein kinase activity to homogeneity from human placenta. Proc. Natl. Acad. Sci. USA 81, 3327-3331

Rees-Jones R.W., Hedo J.A., Zick Y. \& Roth J. (1983) Insulin-stimulated phosphorylation of the insulin receptor precursor. Biochem. Biophys. Res. Commun. 116, 417-422

Rees-Jones R.W. \& Taylor S.I. (1985) An endogenous substrate for the insulin receptorassociated tyrosine kinase. J. Biol. Chem. 260 , 4461-4467

Rosen O.M., Herrera R., Olowe Y., Petruzzelli L.M. \& Cobb M.H. (1983) Phosphorylation activates the insulin receptor tyrosine protein kinase. Proc. Natl. Acad. Sci. USA 80, 3237-3242

Roth R.A. \& Cassel D.J. (1983) Insulin receptor: Evidence that it is a protein kinase. Science 219, 299-301

Roth R.A., Cassel D.K., Maddux D.A. \& Goldfine I.D. (1983) Regulation of insulin receptor kinase activity by insulin mimickers and an insulin antagonist. Biochem. Biophys. Res. Commun. 115, 245-252

Roth R.A. \& Beaudoin J. (1987) Phosphorylation of purified insulin receptor by CAMP kinase. Diabetes 36, 123-126

Sadoul J.L., Peyron J.F., Ballotti R., Debant A., Fehlmann M. \& Van Obberghen E. (1985) Identification of a cellular $110000 \mathrm{Da}$ protein substrate for the insulin receptor kinase. Biochem. J. 227, 887-892

Shia M.A. \& Pilch P.F. (1983) The $\beta$ subunit of the insulin receptor is an insulin-activated protein kinase. Biochemistry 22, 717-721

Stadtmauer L. \& Rosen O.M. (1986) Increasing the cAMP content of IM-9 cells alters the phosphorylation state and protein kinase activity of the insulin receptor. J. Biol. Chem. 261, 34023407 
Tamura S., Fujita-Yamaguchi Y. \& Larner J. (1983) Insulin-like effect of trypsin on the phosphorylation of rat adipocyte insulin receptor. $J$. Biol. Chem. 258, 14749-14752

Tanti J.F., Grémeaux T., Brandenburg D., Van Obberghen E. \& Le Marchand-Brustel Y. (1986) Brown adipose tissue in lean and obese mice : insulin-receptor binding and tyrosine kinase activity. Diabetes 35, 1243-1248

Ullich A., Bell J.R., Chen E.Y., Herrera R., Petruzzelli L.M., Dull T.J., Gray A., Coussens L., Liao Y.C., Tsubokawa M., Mason A., Seeburg P.H., Grunfeld C., Rosen O.M. \& Ramachandran J. (1985) Human insulin receptor and its relationship to the tyrosine kinase family of oncogenes. Nature 313, 756-761

Van Obberghen E. (1984) The insulin receptor : its structure and function. Biochem. Pharmacology, 33, 59-65

Van Obberghen E. \& Kowalski A. (1982) Phosphorylation of the hepatic insulin receptor: stimulating effect of insulin on intact cells and in a cell-free system. FEBS Lett. 143, 179-182
Van Obberghen E., Rossi B., Kowalski A., Gazzano H. \& Ponzio G. (1983) Receptormediated phosphorylation of the hepatic insulin receptor : evidence that the $M_{r} 95000$ receptor subunit is its own kinase. Proc. Natl. Acad. Sci. USA 80, 945-949

White M.F., Maron R. \& Kahn C.R. (1985a) Insulin rapidly stimulates tyrosine phosphorylation of a $M_{r}-185000$ protein in intact cells. Nature 318, 183-186

White M.F., Takayama S. \& Kahn C.R. (1985b) Differences in the sites of phosphorylation of the insulin receptor in vivo and in vitro. J. Biol. Chem. 260, 9470-9478

Yu K.T. \& Czech M.P. (1984) Tyrosine phosphorylation of the insulin receptor $\beta$ subunit activates the receptor-associated tyrosine kinase activity. J. Biol. Chem. 259, 5277-5286

Zick Y., Grunberger G., Podskalny J.M., Moncada V., Taylor S.I., Gorden P. \& Roth J. (1983) Insulin stimulates phosphorylation of serine residues in soluble insulin receptors. Biochem. Biophys. Res. Commun. 116, 1129-1135 